Eur. J. Clin. Chem. Clin. Biochem.

Vol. 31, 1993, pp. 121-128

(C) 1993 Walter de Gruyter \& Co.

Berlin $\cdot$ New York

\title{
Biochemical Diagnosis of a Fatal Case of Günther's Disease in a Newborn with Hydrops Foetalis
}

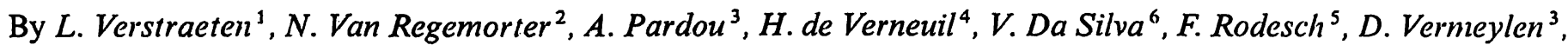
C. Donner ${ }^{2}$, J. C. Noël ${ }^{2}, Y$. Nordmann ${ }^{6}$ and A. Hassoun ${ }^{1}$

1 Department of Clinical Biochemistry, Université Catholique de Louvain, Cliniques Universitaires St Luc, Bruxelles, Belgique

2 Department of Genetics, Faculté de Médecine, Université Libre de Bruxelles, Bruxelles, Belgique

${ }^{3}$ Department of Neonatal Intensive and Non-Intensive Care Unit, Hôpital Universitaire Erasme, Université Libre de Bruxelles, Bruxelles, Belgique

${ }^{4}$ Department of Clinical Biochemistry, Université de Bordeaux II, Bordeaux, France

5 Department of Gynecology and Obstetrics, Hôpital Universitaire Erasme, Université Libre de Bruxelles, Bruxelles, Belgique

6 Department of Biochemistry, Faculté de Médecine Xavier Bichat, Hôpital Louis Mourier, Colombes, France

(Received Seplember 23/November 20, 1992)

Summary: The birth of a male baby was induced at 32 weeks. In utero, the child presented, inter alia, signs of hydrops, hepatosplenomegaly and anaemia. Two in utero transfusions for correction of the anaemia were performed at 28 and 29 weeks, respectively. The baby rapidly presented respiratory distress with mixed acidosis. Three hours after birth, pink urine was excreted. Signs of icterus necessitated phototherapy, after which photosensitivity occurred. Erythrocytes were fluorescent under long-wavelength UV light. The baby died 24 hours after birth, displaying severe acidosis, a diffuse haemorrhagic syndrome, and repeated bradycardia which did not respond to isoprenaline.

The analysis of porphyrins in urine, blood and faeces of the baby gave the following results:

1) uroporphyrin (I and III isomeric series) was increased in urine and faeces, with traces in erythrocytes and plasma;

2) heptacarboxyporphyrin I was found mainly in urine and much less in erythrocytes, plasma and faeces;

3) coproporphyrin I was increased in urine, erythrocytes, plasma and faeces, and

4) 5-aminolaevulinic acid and porphobilinogen in urine and plasma were within the reference ranges.

Determination of the enzymes of haem biosynthesis in erythrocytes and lymphocytes showed that both parents possessed only $50 \%$ of the normal activity of cosynthase.

A previously described point mutation in codon 73 was observed in one parent. Fatal cases of neonatal Günther's disease are extremely rare and such an observation, according to our knowledge, is probably one of the first described.

\section{Introduction}

Günther's disease, also called congenital erythropoietic porphyria (CEP), is a very rare (less than 200 cases reported) type of porphyria $(1,2)$. Congenital erythropoietic porphyria is characterized by an overproduction of porphyrins of isomer I series, with accumulation of thesc compounds in bone marrow erythroblasts, teeth and bones $(1,2)$. These porphyrins 
are excreted in excess in urine and faeces $(1,2)$. Patients with congenital erythropoietic porphyria show an inability to maintain the normal production of porphyrins of isomer III type, consistent with diminished activity of uroporphyrinogen III synthase $e^{l}$ ) (or cosynthetase or hydroxymethylbilane hydrolase cyclizing, EC 3.2.1.75) (3). Congenital erythropoietic porphyria is inherited as a Mendelian autosomal recessive trait (4). The onset of the majority of cases occurs before the 6 th year of life and the main symptoms are cutaneous photosensitivity and haemolysis (5). Congenital erythropoietic porphyria is very rarely detected in utero or at birth $(6,7,8)$.

Our patient is a male premature neonate. Birth was induced at 32 weeks, because he presented in utero, inter alia, signs of hydrops, hepatosplenomegaly and anaemia. Two in utero transfusions for correction of the anaemia were performed at 28 and 29 weeks, respectively. The patient rapidly presented respiratory distress with mixed acidosis.

Three hours after birth, pink urine was excreted. Signs of icterus necessitated phototherapy, after which marked photosensitivity occurred. Red blood cells and bone marrow erythroblasts were fluorescent (red) under long-wavelength UV light.

The baby died $24 \mathrm{~h}$ after birth, displaying severe acidosis, a diffuse haemorrhagic syndrome, and repeated bradycardia which did not respond to isoprenaline (Isuprel $\left.{ }^{\mathbb{E}}\right)$.

This study describes the contribution of biochemical investigations to the diagnosis of this rare type of porphyria, associated with unusual clinical onset. We also report the investigation of porphyrin metabolism in the parents.

\section{Materials and Methods}

Urinary 5-aminolaevulinic acid and porphobilinogen were determined spectrophotometrically after elution from ion-exchange resins (Bio-Rad, Germany), according to Mauzerall \& Granick (9).

Tab. 1. Erythrocyte porphyrins

\begin{tabular}{|c|c|c|c|c|c|}
\hline Porphyrins & & Patient & Father & Mother & $\begin{array}{l}\text { Reference } \\
\text { values }\end{array}$ \\
\hline $\begin{array}{l}\text { Uroporphyrin fraction } \\
\text { Octacarboxyporphyrin } \\
\text { Heptacarboxyporphyrin }\end{array}$ & $\begin{array}{l}(\mathrm{nmol} / \mathrm{l}) \\
(\mathrm{nmol} / \mathrm{l}) \\
(\mathrm{nmol} / \mathrm{l})\end{array}$ & $\begin{array}{l}\text { traces } \\
\text { traces } \\
\text { traces }\end{array}$ & $\begin{array}{r}32 \\
32 \\
\mathrm{ND}\end{array}$ & $\begin{array}{r}26 \\
26 \\
\mathrm{ND}\end{array}$ & $<50$ \\
\hline $\begin{array}{l}\text { Coproporphyrin fraction } \\
\text { Hexacarboxyporphyrin } \\
\text { Pentacarboxyporphyrin } \\
\text { Tetracarboxyporphyrin }\end{array}$ & $\begin{array}{l}(\mathrm{nmol} / \mathrm{l}) \\
(\mathrm{nmol} / \mathrm{l}) \\
(\mathrm{nmol} / \mathrm{l}) \\
(\mathrm{nmol} / \mathrm{l})\end{array}$ & $\begin{array}{l}1715 \\
\text { ND } \\
\text { ND } \\
1715\end{array}$ & $\begin{array}{r}34 \\
7 \\
9 \\
18\end{array}$ & $\begin{array}{r}71 \\
10 \\
8 \\
53\end{array}$ & $<100$ \\
\hline $\begin{array}{l}\text { Protoporphyrin fraction } \\
\text { Protoporphyrin } \\
\text { Zinc protoporphyrin }\end{array}$ & $\begin{array}{l}(\mathrm{nmol} / \mathrm{l}) \\
(\mathrm{nmol} / \mathrm{l}) \\
(\mathrm{nmol} / \mathrm{l})\end{array}$ & $\begin{array}{l}58 \\
48 \\
10\end{array}$ & $\begin{array}{r}110 \\
43 \\
67\end{array}$ & $\begin{array}{r}163 \\
141 \\
22\end{array}$ & $<500$ \\
\hline \multicolumn{6}{|l|}{ Isomer fractionation } \\
\hline \begin{tabular}{cc}
\multicolumn{2}{c}{ Octacarboxyporphyrin } \\
Isomer I & $(\%)$ \\
Isomer III & $(\%)$
\end{tabular} & & $\begin{array}{l}33 \\
67\end{array}$ & $\begin{array}{l}40 \\
60\end{array}$ & $\begin{array}{l}60 \\
40\end{array}$ & $\begin{array}{l}< \\
<30 \\
>70\end{array}$ \\
\hline \begin{tabular}{ll}
\multicolumn{3}{l}{ Heptacarboxyporphyrin } \\
Isomer I & $(\%)$ \\
Isomer III & $(\%)$
\end{tabular} & & $\begin{array}{l}100 \\
\text { ND }\end{array}$ & $\begin{array}{l}\text { ND } \\
\text { ND }\end{array}$ & $\begin{array}{l}\text { ND } \\
\text { ND }\end{array}$ & $\begin{array}{l}<30 \\
>70\end{array}$ \\
\hline \begin{tabular}{lc}
\multicolumn{3}{l}{ Hexacarboxyporphyrin } \\
Isomer I & $(\%)$ \\
Isomer III & $(\%)$
\end{tabular} & & $\begin{array}{l}\text { ND } \\
\text { ND }\end{array}$ & $\begin{array}{l}100 \\
\text { ND }\end{array}$ & $\begin{array}{l}100 \\
\text { ND }\end{array}$ & $\begin{array}{l}<30 \\
>70\end{array}$ \\
\hline $\begin{array}{cc}\text { Pentacarboxyporphyrin } \\
\text { Isomer I } & (\%) \\
\text { Isomer III } & (\%)\end{array}$ & & $\begin{array}{l}\text { ND } \\
\text { ND }\end{array}$ & $\begin{array}{l}45 \\
55\end{array}$ & $\begin{array}{l}\text { ND } \\
100\end{array}$ & $\begin{array}{l}<30 \\
>70\end{array}$ \\
\hline \begin{tabular}{cc}
\multicolumn{2}{c}{ Tetracarboxyporphyrin } \\
Isomer I & $(\%)$ \\
Isomer III & $(\%)$
\end{tabular} & & $\begin{array}{r}95 \\
5\end{array}$ & $\begin{array}{l}40 \\
60\end{array}$ & $\begin{array}{l}27 \\
73\end{array}$ & $\begin{array}{l}<30 \\
>70\end{array}$ \\
\hline
\end{tabular}


Urinary and faecal porphyrins were determined by high performance liquid chromatography (HPLC) as previously described (9).

Plasma porphyrins were determined by HPLC, using a method derived from that of Longas \& Poh-Fitzpatrick (10).

Erythrocyte porphyrins were determined by HPLC, using a method derived from that of Scoble et al. (11).

Isomers I and III in urine, faeces, plasma and erythrocytes were fractionated by HPLC, using a method derived from that of Lim et al. (12).

Uroporphyrinogen III synthase activity in erythrocytes (both parents) was determined as previously described (8).

5-Aminolaevulinate dehydratase (EC 4.2.1.24), porphobilinogen deaminase (EC 4.3.1.8) and uroporphyrinogen decarboxylase (EC 4.1.1.37) activities') were determined in erythrocytes as previously described $(9,13)$.

Coproporphyrinogen oxidase (EC 1.3.3.3) and protoporphyrinogen oxidase (EC 1.3.3.4) activities') were determined in lymphocytes as previously described $(14,15)$.

\section{Results}

Some features of the clinical investigation (emission of pink urine, hirsutism, photosensitivity) and the erythrocyte fluorescence under long-wavelength UV led us to a more detailed investigation of porphyrin metabolism, including the fractionation of isomers I and III, and determination of the enzymes of haem biosynthesis. This study was performed on the patient and his two parents.

Tables 1 to 4 present the results of porphyrin determinations in plasma, erythrocytes, urine and faeces.

In the patient, tetracarboxyporphyrin (almost exclusively isomer I) was strongly increased in erythrocytes, plasma, urine and faeces. Octacarboxyporphyrin (a mixture of isomers I and III) was strongly increased in urine and to a lesser degree in faeces. Heptacarboxyporphyrin (isomer I) was increased in urine, and to a lesser degree in plasma, erythrocytes and faeces.

Table 5 shows the results for several enzymes of haem biosynthesis.

\section{Discussion}

Although one of the rarest of the porphyrias, congenital erythropoietic porphyria was the first of these diseases recorded in the literature, probably because

Tab. 2. Plasma porphyrins and precursors

\begin{tabular}{|c|c|c|c|c|c|}
\hline & & Patient & Father & Mother & $\begin{array}{l}\text { Reference } \\
\text { values }\end{array}$ \\
\hline 5-Aminolaevulinic acid $(\mu \mathrm{n}$ & nol/1) & not determined & 0.1 & 0.1 & $<0.6$ \\
\hline Porphobilinogen $(\mu \mathrm{mol} / \mathrm{l})$ & & nol determined & 0.1 & 0.2 & $<0.2$ \\
\hline $\begin{array}{l}\text { Uroporphyrin fraction } \\
\text { Octacarboxyporphyrin } \\
\text { Heptacarboxyporphyrin }\end{array}$ & $\begin{array}{l}(\mathrm{nmol} / \mathrm{l}) \\
(\mathrm{nmol} / \mathrm{l}) \\
(\mathrm{nmol} / \mathrm{l})\end{array}$ & $\begin{array}{c}6 \\
\text { traces } \\
6\end{array}$ & $\begin{array}{l}\text { traces } \\
\text { traces } \\
\text { ND }\end{array}$ & $\begin{array}{l}\text { traces } \\
\text { traces } \\
\mathrm{ND}\end{array}$ & $<5$ \\
\hline $\begin{array}{l}\text { Coproporphyrin fraction } \\
\text { Hexacarboxyporphyrin } \\
\text { Pentacarboxyporphyrin } \\
\text { Tetracarboxyporphyrin }\end{array}$ & $\begin{array}{l}(\mathrm{nmol} / \mathrm{l}) \\
(\mathrm{nmol} / \mathrm{l}) \\
(\mathrm{nmol} / \mathrm{l}) \\
(\mathrm{nmol} / \mathrm{l})\end{array}$ & $\begin{array}{l}4053 \\
\text { ND } \\
\text { ND } \\
4053\end{array}$ & $\begin{array}{r}4 \\
\mathrm{ND} \\
4 \\
\mathrm{ND}\end{array}$ & $\begin{array}{l}12 \\
N D \\
12 \\
\text { traces }\end{array}$ & $<10$ \\
\hline Protoporphyrin (nmol/l) & & 54 & 27 & 41 & $<50$ \\
\hline \multicolumn{6}{|l|}{ Isomer fractionation } \\
\hline \begin{tabular}{cc}
\multicolumn{3}{c}{ Octacarboxyporphyrin } \\
Isomer I & $(\%)$ \\
Isomer III & $(\%)$
\end{tabular} & & $\begin{array}{l}50 \\
50\end{array}$ & $\begin{array}{l}\text { ND } \\
100\end{array}$ & $\begin{array}{l}50 \\
50\end{array}$ & $\begin{array}{l}<30 \\
>70\end{array}$ \\
\hline $\begin{array}{l}\text { Heptacarboxyporphyrin } \\
\text { Isomer I } \quad(\%) \\
\text { Isomer III } \\
\text { (\%) }\end{array}$ & & $\begin{array}{l}100 \\
\text { ND }\end{array}$ & $\begin{array}{l}\text { ND } \\
\text { ND }\end{array}$ & $\begin{array}{l}\text { ND } \\
\text { ND }\end{array}$ & $\begin{array}{l}<30 \\
>70\end{array}$ \\
\hline $\begin{array}{cc}\text { Hexacarboxyporphyrin } \\
\text { Isomer I } & (\%) \\
\text { Isomer III } & (\%)\end{array}$ & & $\begin{array}{l}\text { ND } \\
\text { ND }\end{array}$ & $\begin{array}{l}\text { ND } \\
\text { ND }\end{array}$ & $\begin{array}{l}\text { ND } \\
\text { ND }\end{array}$ & $\begin{array}{l}<30 \\
>70\end{array}$ \\
\hline $\begin{array}{cc}\text { Pentacarboxyporphyrin } \\
\text { Isomer I } & (\%) \\
\text { Isomer III } & (\%)\end{array}$ & & $\begin{array}{l}\text { ND } \\
\text { ND }\end{array}$ & $\begin{array}{l}\text { ND } \\
100\end{array}$ & $\begin{array}{l}35 \\
65\end{array}$ & $\begin{array}{l}<30 \\
>70\end{array}$ \\
\hline $\begin{array}{cc}\text { Tetracarboxyporphyrin } \\
\text { Isomer I } & (\%) \\
\text { Isomer III } & (\%)\end{array}$ & & $\begin{array}{l}100 \\
\text { ND }\end{array}$ & $\begin{array}{l}\text { ND } \\
\text { ND }\end{array}$ & $\begin{array}{l}100 \\
\text { ND }\end{array}$ & $\begin{array}{l}<30 \\
>70\end{array}$ \\
\hline
\end{tabular}


Tab. 3. Urine porphyrins and precursors

\begin{tabular}{|c|c|c|c|c|}
\hline & Patient. & Father & Mother & $\begin{array}{l}\text { Reference } \\
\text { values }\end{array}$ \\
\hline $\begin{array}{l}\text { 5-Aminolaevulinic acid } \\
(\mu \mathrm{mol} / \mathrm{g} \text { creatinine })\end{array}$ & 26 & 8 & 10 & $<25$ \\
\hline $\begin{array}{l}\text { Porphobilinogen } \\
(\mu \mathrm{mol} / \mathrm{g} \text { creatinine })\end{array}$ & ND & 1 & 1 & $<5$ \\
\hline $\begin{array}{l}\text { Uroporphyrin fraction } \\
\text { (nmol/g creatinine) }\end{array}$ & 166539 & 31 & 10 & $<110$ \\
\hline $\begin{array}{l}\text { Octacarboxyporphyrin } \\
\text { (nmol/g creatinine) }\end{array}$ & 154920 & 31 & 10 & \\
\hline $\begin{array}{l}\text { Heptacarboxyporphyrin } \\
\text { (nmol/g creatinine) }\end{array}$ & 11619 & ND & traces & \\
\hline $\begin{array}{l}\text { Coproporphyrin fraction } \\
\text { (nmol/g creatinine) }\end{array}$ & 266232 & 340 & 386 & $<740$ \\
\hline $\begin{array}{l}\text { Hexacarboxyporphyrin } \\
\text { (nmol/g creatinine) }\end{array}$ & ND & $\mathrm{ND}$ & ND & \\
\hline $\begin{array}{l}\text { Pentacarboxyporphyrin } \\
\text { (nmol/g creatinine) }\end{array}$ & 18682 & ND & ND & \\
\hline $\begin{array}{l}\text { Tetracarboxyporphyrin } \\
\text { (nmol/g creatinine) }\end{array}$ & 247549 & 340 & 386 & \\
\hline \multicolumn{5}{|l|}{ Isomer fractionation } \\
\hline \multicolumn{5}{|l|}{ Octacarboxyporphyrin } \\
\hline $\begin{array}{ll}\text { Isomer I } & (\%) \\
\text { Isomer III } & (\%)\end{array}$ & $\begin{array}{l}43 \\
57\end{array}$ & $\begin{array}{l}50 \\
50\end{array}$ & $\begin{array}{l}35 \\
65\end{array}$ & $\begin{array}{l}<30 \\
>70\end{array}$ \\
\hline \multicolumn{5}{|l|}{ Heptacarboxyporphyrin } \\
\hline Isomer I $\quad(\%)$ & 100 & ND & 60 & $<30$ \\
\hline Isomer III $\quad(\%)$ & ND & ND & 40 & $>70$ \\
\hline \multicolumn{5}{|l|}{ Hexacarboxyporphyrin } \\
\hline Isomer I $\quad(\%)$ & ND & ND & ND & $<30$ \\
\hline Isomer III $\quad(\%)$ & ND & ND & ND & $>70$ \\
\hline \multicolumn{5}{|l|}{ Pentacarboxyporphyrin } \\
\hline Isomer I $\quad$ \%) & 100 & ND & 100 & $<30$ \\
\hline Isomer III $\quad(\%)$ & ND & ND & ND & $>70$ \\
\hline \multicolumn{5}{|l|}{ Tetracarboxyporphyrin } \\
\hline $\begin{array}{ll}\text { Isomer I } & (\%) \\
\text { Isomer III } & (\%)\end{array}$ & $\begin{array}{r}99 \\
1\end{array}$ & 97 & 45 & $<30$ \\
\hline & 1 & 3 & 55 & $>70$ \\
\hline
\end{tabular}

of the severity of its cutaneous symptoms (16). Congenital erythropoietic porphyria is a very rare disease (less than 200 cases reported in the literature). Higher prevalences reported previously are explained by confusion with early-onset cases of cutaneous hepatic porphyria $(17,18,19)$.

The pattern of porphyrin overproduction in congenital erythropoietic porphyria indicates that the block in the haem synthetic pathway occurs at the level of uroporphyrinogen III synthase $(3,20-25)$. This enzyme catalyses the formation of uroporphyrinogen III from hydroxymethylbilane or from porphobilinogen if porphobilinogen deaminase is present (2). Patients with congenital erythropoietic porphyria demonstrate an inability to maintain the normal production of series III isomers, consistent with a diminished activity of uroporphyrinogen III synthase (3).
Erythrocyte uroporphyrinogen III synthase activity in both parents of our patient is about $50 \%$ of the normal value, which is compatible with an heterozygous state for congenital erythropoietic porphyria (26).

Although there is a deficiency of uroporphyrinogen III synthase, it does not completely block the synthesis of series III isomer porphyrins $(1,2)$. Indeed, as stated previously, there is some increase in total porphyrin synthesis, as evidenced by increased concentrations in peripheral blood and urine $(1,2)$. In our patient, we observed a large predominance of type-I isomers of tetra; penta- and heptacarboxyporphyrins in all the biological material examined (erythrocytes, plasma, urine and faeces). The octacarboxyporphyrins were detected in small amounts in erythrocytes, plasma and faeces, and high quantities were excreted in urine. 
Tab. 4. Faccal porphyrins

\begin{tabular}{|c|c|c|c|c|}
\hline Porphyrins & Patient & Father & Mother & $\begin{array}{l}\text { Reference } \\
\text { values }\end{array}$ \\
\hline $\begin{array}{l}\text { Uroporphyrin fraction } \\
\text { (nmol/g dry weight) }\end{array}$ & 22 & 3 & 6 & ND \\
\hline $\begin{array}{l}\text { Octacarboxyporphyrin } \\
\text { (nmol/g dry weight) }\end{array}$ & 14 & 1 & 4 & \\
\hline $\begin{array}{l}\text { Heptacarboxyporphyrin } \\
\text { (nmol/g dry weight) }\end{array}$ & 8 & 2 & 2 & \\
\hline $\begin{array}{l}\text { Coproporphyrin fraction } \\
\text { (nmol/g dry weight) }\end{array}$ & 2132 & 34 & 10 & $<110$ \\
\hline $\begin{array}{l}\text { Hexacarboxyporphyrin } \\
\text { (nmol/g dry weight) }\end{array}$ & ND & ND & ND & \\
\hline $\begin{array}{l}\text { Pentacarboxyporphyrin } \\
\text { (nmol/g dry weight) }\end{array}$ & 43 & ND & ND & \\
\hline $\begin{array}{l}\text { Tetracarboxyporphyrin } \\
\text { (nmol/g dry weight) }\end{array}$ & 2089 & 34 & 10 & \\
\hline $\begin{array}{l}\text { Protoporphyrin } \\
\text { (nmol/g dry weight) }\end{array}$ & 61 & 1 & 1 & $<90$ \\
\hline \multicolumn{5}{|l|}{ Isomer fractionation } \\
\hline \begin{tabular}{cc}
\multicolumn{3}{c}{ Octacarboxyporphyrin } \\
Isomer I & $(\%)$ \\
Isomer III & $(\%)$
\end{tabular} & $\begin{array}{l}35 \\
65\end{array}$ & $\begin{array}{l}65 \\
35\end{array}$ & $\begin{array}{l}40 \\
60\end{array}$ & $\begin{array}{l}<30 \\
>70\end{array}$ \\
\hline 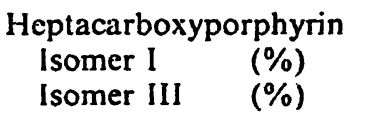 & $\begin{array}{l}100 \\
\text { ND }\end{array}$ & $\begin{array}{l}\text { ND } \\
100\end{array}$ & $\begin{array}{l}20 \\
80\end{array}$ & $\begin{array}{l}<30 \\
>70\end{array}$ \\
\hline $\begin{array}{cc}\text { Hexacarboxyporphyrin } \\
\text { Isomer I } & (\%) \\
\text { Isomer III } & (\%)\end{array}$ & $\begin{array}{l}\text { ND } \\
\text { ND }\end{array}$ & $\begin{array}{l}\text { ND } \\
\text { ND }\end{array}$ & $\begin{array}{l}\text { ND } \\
\text { ND }\end{array}$ & $\begin{array}{l}<30 \\
>70\end{array}$ \\
\hline $\begin{array}{lc}\text { Pentacarboxyporphyrin } \\
\text { Isomer I } & (\%) \\
\text { Isomer III } & (\%)\end{array}$ & $\begin{array}{l}100 \\
\text { ND }\end{array}$ & $\begin{array}{l}\text { ND } \\
\text { ND }\end{array}$ & $\begin{array}{l}\text { ND } \\
\text { ND }\end{array}$ & $\begin{array}{l}<30 \\
>70\end{array}$ \\
\hline \begin{tabular}{cc}
\multicolumn{2}{c}{ Tetracarboxyporphyrin } \\
Isomer I & $(\%)$ \\
Isomer III & $(\%)$
\end{tabular} & $\begin{array}{l}100 \\
\text { ND }\end{array}$ & $\begin{array}{l}85 \\
15\end{array}$ & $\begin{array}{l}80 \\
20\end{array}$ & $\begin{array}{l}50-70 \\
30-50\end{array}$ \\
\hline
\end{tabular}

Tab. 5. Haem biosynthesis enzymes determination

\begin{tabular}{|c|c|c|c|}
\hline Enzyme & Father & Mother & $\begin{array}{l}\text { Reference } \\
\text { values }\end{array}$ \\
\hline $\begin{array}{l}\text { Erythrocyte } 5 \text {-aminolaevulinate dehydratase } \\
\left(5 \text {-aminolaevulinate, } \mu \mathrm{mol} / \mathrm{min} \cdot 1 \text { erythrocytes at } 37^{\circ} \mathrm{C}\right)\end{array}$ & 38 & 43 & $20-60$ \\
\hline $\begin{array}{l}\text { Erythrocyte porphobilinogen deaminase } \\
\quad \text { (uroporphyrin, pmol/h } \cdot \mathrm{mg} \text { haemoglobin at } 37^{\circ} \mathrm{C} \text { ) }\end{array}$ & 142 & 178 & $103-243$ \\
\hline $\begin{array}{l}\text { Erythrocyte uroporphyrinogen cosynthase } \\
\text { (cosynthase, units/mg protein at } 37^{\circ} \mathrm{C} \text { ) }\end{array}$ & 5.0 & 5.5 & $8.0-12.0$ \\
\hline $\begin{array}{l}\text { Erythrocyte uroporphyrinogen decarboxylase } \\
\text { (coproporphyrinogen, nmol/h } \cdot \mathrm{mg} \text { protein at } 37^{\circ} \mathrm{C} \text { ) }\end{array}$ & 40 & 36 & $30-70$ \\
\hline $\begin{array}{l}\text { Lymphocyte coproporphyrinogen oxidase } \\
\text { (protoporphyrin, pmol/mg protein at } 37^{\circ} \mathrm{C} \text { ) }\end{array}$ & 706 & 499 & $350-650$ \\
\hline $\begin{array}{l}\text { Lymphocyte protoporphyrinogen oxidase } \\
\text { (protoporphyrin, nmol/h } \cdot \mathrm{mg} \text { protein at } 37^{\circ} \mathrm{C} \text { ) }\end{array}$ & 5.2 & 5.0 & $3.6-6.0$ \\
\hline
\end{tabular}


In all these biological fluids, the ratio of isomer I to isomer III varied from 30 to $50 \%$.

Furthermore, increased concentrations of erythrocyte porphyrins have been found in relatives of congenital erythropoietic porphyria patients, consistent with a partial deficiency of uroporphyrinogen III synthase in heterozygotes $(3,27-29)$. In our study, plasma and erythrocyte porphyrins were within reference range for both parents. The patient showed extremely high concentrations of plasma and erythrocyte coproporphyrin, almost exclusively of the type-I isomer.

Typically, the urinary total porphyrin concentration in congenital erythropoietic porphyria is between 20000 and $90000 \mathrm{nmol} / \mathrm{l}$ (2). This consists mainly of uroporphyrin and heptacarboxylic porphyrin, with $10-20 \%$ coproporphyrin $(30,31)$. In our patient, urine total porphyrin concentration was about $430000 \mathrm{nmol} / \mathrm{l}$. Coproporphyrin (almost exclusively type-I isomer) is predominant in urine. Both parents have urine porphyrin values within the reference range, but the father excretes predominantly type-I coproporphyrin. It is to be noted that the coproporphyrin in normal urine consists of $70 \%$ isomer III and $30 \%$ isomer I (32). An increased ratio of coproporphyrin I to coproporphyrin III may be observed in other diseases such as cholestasis and Dubin-Johnson syndrome $(33,34)$. Excessive production of intermediate porphyrins, as found by HPLC, also occurs in cutaneous hepatic porphyria, but the pattern of excreted compounds is quite different $(1,2)$. Isomeric fractionation shows that more than $80 \%$ of the total porphyrin is of series I, although, as stated before, there is also an overall increase in the production and excretion of uroporphyrinogen III $(1,2)$. Concerning uroporphyrin, isomeric fractionation reveals a mixture of isomers I and III in all samples examined, whereas the typical pattern shows a predominance of type-I isomers (1). The predominance of uroporphyrin I over uroporphyrin III may also be observed in cases of cutaneous hepatic porphyria (35).

Faecal porphyrins are usually elevated in congenital erythropoietic porphyria, consisting predominantly of coproporphyrin, with a variable, but usually slight increase in protoporphyrin $(1,2)$. Uroporphyrin is also normally detectable in the faeces $(1,2)$. Unlike cutaneous hepatic porphyria, the isocoproporphyrin series of porphyrins is not detected $(1,2)$. In our patient, faecal coproporphyrin is strongly increased, together with a mild increase of uroporphyrin, heptaand pentacarboxyporphyrins.

The strong increase of coproporphyrin in all biological samples led us to consider the diagnosis of a coexistent hereditary coproporphyria, an association previously described in a young female patient (36). This diagnosis was ruled out by the presence of normal values for lymphocyte coproporphyrinogen oxidase observed in both parents. The presence in all biological samples examined (erythrocytes, plasma, urine, faeces) of high concentrations of coproporphyrins, consisting of nearly $100 \%$ of the isomer I series, also excluded the diagnosis of hereditary coproporphyria in our patient $(1,2)$.

Concerning differential diagnosis, the laboratory investigations must be used to exclude other forms of porphyria, particularly any of the extremely rare cases of homozygous porphyria, as found in cutaneous hepatic porphyria and hereditary coproporphyria (1, 2). This diagnosis was excluded by the normal values of uroporphyrinogen decarboxylase and coproporphyrinogen oxidase in both parents, together with protoporphyrinogen oxidase.

With respect to the pathogenesis of cutaneous lesions (major photosensitivity observed after phototherapy, applied in this case because of icterus), many of the features of congenital erythropoietic porphyria differ only in severity from those found in other cutaneous porphyrias, such as cutaneous hepatic porphyria (1, 2). Our patient shows moderate hirsutism, which is commonly observed in cases of congenital erythropoietic porphyria $(1,2)$.

The majority of the patients presenting congenital erythropoietic porphyria suffer from haemolytic anaemia $(1,2)$. In this case, anaemia (haemoglobin concentration: $72 \mathrm{~g} / \mathrm{l}$ ) was diagnosed at 28 weeks and was treated by two in utero transfusions at 28 and 29 weeks. Indirect and direct Coomb's tests were negative. Haemolysis seems to be associated with an increased osmotic fragility of erythrocytes, due to increased concentrations of erythrocyte porphyrins (37). Porphyrin deposition may also be found in bone marrow (38), where between 30 and $70 \%$ of the erythroblasts show porphyrin fluorescence (fluorocytes), i.e. bright red fluorescence is observed under longwavelength UV light (38); this was also observed in our case.

The patient showed marked hepatosplenomegaly. In congenital erythropoietic porphyria, the liver in particular makes a significant contribution to excessive porphyrin synthesis (39). Splenomegaly is always observed in cases of congenital erythropoietic porphyria $(1,2)$. There are no characteristic histological findings in the spleen other than the manifestations of haemolysis $(1,2)$.

Congenital erythropoietic porphyria is expressed very rarely in utero, as is shown by the autopsy on a 
newborn child (40), by diagnosis at birth (6) and by prenatal diagnosis $(7,8)$. Reddish-brown amniotic fluid with an increased porphyrin content is usually encountered early in the second trimester of pregnancy in fetuses with congenital erythropoietic porphyria $(7,41)$. In the present case, this fluid was colourless.

One of the earliest signs of the disease may be the excretion of reddish-coloured urine $(1,2)$. Emission of pink urine after three hours of life, together with a naso-pharyngal and gastric aspiration of pink liquid was observed in our case.

The patient shows the criteria of neonatal congenital erythropoietic porphyria, according to Schwartz:

1) emission of red urine together with an increase of uroporphyrins and coproporphyrins and normal concentrations of 5-aminolaevulinic acid and porphobilinogen;

2) presence of splenomegaly and haemolytic anaemia;

3) red fluorescence of the bone marrow (14).

Clinically, congenital erythropoietic porphyria may be distinguished from early-onset cutaneous hepatic porphyria by the presence of splenomegaly, erythrodontia (due to porphyrin accumulation in teeth, pathognomonic of congenital erythropoietic porphyria), anaemia and erythrocyte fluorescence $(1,2)$.

Congenital erythropoietic porphyria is inherited in an autosomal recessive fashion $(1,2)$. In this family, both parents are asymptomatic and heterozygous for congenital erythropoietic porphyria. Their first child was in good health. The second child died in utero at 33 weeks under very similar conditions to those observed

\section{References}

1. Moore, M. R., Mc Coll, K. E. L., Rimington, C. \& Goldberg, A. (1987) Congenital porphyria. In: Disorders of Porphyrin Metabolism, pp. 213-226, Plenum Publishing Corporation, New York.

2. Kappas, A., Sassa, S., Galbraith, R. A. \& Nordmann, Y. (1989) The porphyrias. In: The Metabolic Basis of Inherited Diseases, pp. 1305-1365 (Scriver, C. R., Beaudet, A. L., Sly, W. S. \& Yale, D., eds.) Mạc Graw-Hill Book Company, New York.

3. Romeo, G. \& Levin, E. Y. (1969) Uroporphyrinogen III cosynthetase in human congenital erythropoietic porphyria. Proc. Natl. Acad. Sci. U. S. A. 63, 856-869.

4. Darocha, T., Weremowicz, J. \& Gregor, A. (1971) Family study in congenital erythropoietic porphyria. S. Afr. J. Lab. Clin. Med. 17, 231-236.

5. Mascaro-Galey, C., Mascaro, J. M. \& Albero, F. (1977) Porphyrie érythropoïetique congénitale de Günther chez une fillette de huit mois. Ann. Dermatol. Venerol. 104, $32-37$. in the present case (their third child): hydrops foetalis with hepatosplenomegaly compatible with an haemolytic anaemia (Coomb's test was negative) and extramedullar erythropoiesis.

The isolation and sequencing of a full-length complementary DNA (cDNA) encoding uroporphyrinogen III synthase allows the study of the enzymatic defect at the molecular level (42). Different point mutations, insertions or deletions have been detected $(43-45)$. It has now been shown that one of the parents carries the C $73 \mathrm{R}$ mutation (a cysteine replaced by an arginine at position 73 in the protein), which has been previously described (43).

\section{Conclusion}

A fatal case of Günther's disease (congenital erythropoietic porphyria) is reported in a baby whose birth was induced at 32 weeks. The biochemical diagnosis was made on the basis of:

1. a massive increase, in erythrocytes, plasma, urine and faeces, of type-I porphyrins (mainly coproporphyrin);

2. a familial study revealing that both parents are heterozygous for uroporphyrinogen III synthase deficiency;

3. the observation of a point mutation in codon 73 in one parent.

Fatal cases of neonatal congenital erythropoietic porphyria are extremely rare and such an observation, according to our knowledge, is probably one of the first described.

6. Martin, C., Babin, J. P., Sanjuan, B., Demarquez, J. L., Dubernet, C. \& Maillet-Mezeray, G. (1973) Porphyrie érythropoïétique congénitale (maladie de Günther). Une observation diagnostiquée à la naissance. Nouv. Press. Med. $2,2591-2594$.

7. Nitowsky, H. R., Sassa, S., Nakagawa, A. \& Jagani, N. (1978) Prenatal diagnosis of congenital erythropoietic porphyria. Pediatr. Res. 12, 455.

8. Deybach, J. C., Grandchamp, B., Grelier, M., Nordmann, Y., Boué, J., Boué, A. \& de Béranger, P. (1980) Prenatal exclusion of congenital erythropoietic porphyria (Günther's disease) in a foetus at risk. Hum. Genet. 53, 217-221.

9. Hassoun, A., Verstraeten, L., Mercelis, R. \& Martin, J. J. (1989) Biochemical diagnosis of an hereditary aminolaevulinate dehydratase deficiency in a 63-year-old man. J. Clin. Chem. Clin. Biochem. 27, 781-786.

10. Longas, M. O. \& Poh-Fitzpatrick, M. B. (1980) Highpressure liquid chromatography of plasma free acid porphyrins. Anal. Biochem. 104, 268-276. 
11. Scoble. H. A., Mac Keag, M., Brown, P. R. \& Kavaranos, G. J. (1981) The rapid determination of erythrocyte porphyrins using reversc-phase high performance liquid chromatography. Clin. Chim. Acta 113, 253-265.

12. Lim. C. K.. Ridcout, J. M. \& Wright, D. J. (1983) Separation of porphyrin isomers by high performance liquid chromatography. Biochem. J. 211, 435-438.

13. Elder. G. H. \& Wyvill, P. C. (1982) Measurement of uroporphyrinogen decarboxylase using porphyrinogens prepared by chemical reduction. Enzyme 28, 186-195.

14. Grandchamp, B. \& Nordmann, Y. (1982) Coproporphyrinogen III oxidase assay. Enzyme 28, 196-205.

15. Jacobs, N. J. \& Jacobs. J. M. (1982) Assay for enzymatic protoporphyrinogen oxydation, a late step in heme biosynthesis. Enzyme 28, 206-219.

16. Schultz, J. H. (1874) Ein Fall von Pemphigus leprosus, kompliziert durch Lepra visceralis. Inaugural Dissertation, Greifswald.

17. Gajdos, A.. Gajdos-Török, M., Hartleyb, H. \& Lausecker, C. (1963) Un cas de porphyrie congénitale traitée par l'acide adénosine 5 monophosphorique. Press. Med. 71, 12941296.

18. Gajdos, A., Plainfosse. B. \& Seringe, P. (1967) Porphyrie cutanée dite de l'adulte chez un enfant, révélée par une hépatite virale. Traitement par l'acide adénosine 5 monophosphorique. Press. Med. 75, 545-547.

19. Schmid, R., Schwartz, S. \& Sundberg, D. (1955) Erythropoietic congenital porphyria. Blood 10, 416.

20. Levin, E. Y. (1975) Comparative aspects of porphyria in man and animals. Ann. NY. Acad. Sci. 244, 481-492.

21. Watson, C. J.. Runge, W., Taddeini, L., Bossenmaier, I. \& Cardinal, R. (1964) A suggested control gene mechanism for the excessive production of types I and III porphyrins in congenital erythropoietic porphyria. Proc. Natl. Acad. Sci. USA. 52, $478-485$.

22. Eriksen, L. \& Eriksen, N. (1977) Porphyrin distribution and porphyrin excretion in human congenital erythropoietic porphyria. Scand. J. Clin. Lab. Invest. 33, 323-332.

23. Miyagi, K., Petryka, Z. J., Bossenmaier, I., Cardinal, R. \& Watson. C. J. (1976) The activities of uroporphyrin synthesis and cosynthase in congenital erythropoietic porphyria. Am. J. Hematol. 1, 3-21.

24. Moore, M. R., Thompson, G. G., Goldberg, A., Ippen, H., Seubert, A. \& Seubert, S. (1978) The biosynthesis of haem in congenital erythropoietic porphyria. Int. J. Biochem. 9, 933-938.

25. Mukerji, S. K., Pimstone, N. R., Gandhi, S. N. \& Tan, K. T. (1985) Biochemical diagnosis and monitoring therapeutic modulation of disease activity in an unusual case of congenital erythropoietic porphyria. Clin. Chem. 31, 19461951.

26. Deybach, J. C., de Verneuil, H., Phung, N., Nordmann, Y., Puissant, A. \& Boffety, B. (1981) Congenital erythropoietic porphyria (Günther's disease), enzymatic studies on two cases of late onset. J. Lab. Clin. Med. 97, 551-558.

27. Heilmeyer, L., Clotten, R., Kerp, L., Merker, H., Parra, C. A. \& Wetzel, H. P. (1964) Porphyria erythropoietica congenita Günther - Ein Bericht über zwei Familien mit Erfassung der Merkmalsträger. Deutsche Med. Wochenschr. $88,2449-2456$.

28. Heilmeyer, L. (1964) The erythropoietic porphyrias. Acta Haematol. (Basel) 31, 137.

29. Pain, R. W., Welch, F. W., Woodroffe, A. J., Handley, D. A. \& Lockwood, W. L. (1975) Erythropoietic uroporphyria of Günther first presenting at 58 years with positive family studies. Br. Med. J. 3, 621-623.
30. Rimington, C. \& With, T. K. (1973) Porphyrin studies in congenital erythropoietic porphyria. Studies on a sample of faeces and urine from a patient with CEP and comparison with a bovine case. Danish Med. Bull. 20, 5-12.

31. Eriksen, L. \& Eriksen, N. (1977) Urinary excretion of position isomers of penta and hexacarboxylated porphyrins belonging to the isomer III series in a case of human congenital erythropoietic porphyria. Scand. J. Clin. Lab. Invest. 37, 357-361.

32. Borup, P., Kordac, V., Pedersen, J. S. \& With, T. K. (1980) The porphyrin pattern in normal urine. Int. J. Biochem. $12,1075-1080$.

33. Rocchi, E., Gilbertini, P., Santunione, V., Balli, F. \& Ventura, E. (1980) Faecal and urinary coproporphyrin isomers in biliary atresia and neonatal hepatitis. Ricerca Clin. Lab. 10, $501-509$.

34. Kondo, T., Kuchiba, K. \& Shimizu, Y. (1976) Coproporphyrin isomers in Dubin-Johnson syndrome. Gastroenterology 70, 1117-1120.

35. Doss, M., Meinhof, W., Look, D., Henning, H., Nawrocki, P., Dölle, W., Strohmeyer, G. \& Filippini, L. (1971) Porphyrins in liver and urine in acute intermittent and chronic hepatic porphyrias. S. Afr. J. Lab. Clin. Med. 17, 50-54.

36. Nordmann, Y., Amram, D., Deybach, J. C., Phung, L. N. \& Lesbros, D. (1990) Coexistent hereditary coproporphyria and congenital erythropoietic porphyria (Günther disease). J. Inher. Metab. Dis. 13, 687-691.

37. Watson, C. J., Perman, V., Spurrel, F. A., Hoyt, H. H. \& Schwartz, S. (1959) Some studies of the comparative biology of human and bovine erythropoietic porphyria. Arch. Intern. Med. 103, 436-444.

38. Tonz, O., Vogt, J., Filippini, L., Simmler, F., Wachsmuth, D. \& Winterhalter, K. H. (1975) Schwere Lichtdermatose nach Phototherapie bei einem Neugeborenen mit kongenitaler erythropoetischer Uroporphyrie. Helvetica Paediatria $30,47-56$

39. Nicholson, D. C., Cowger, M. L., Kalivas, J., Thompson, R. P. H. \& Gray, C. H. (1973) Isotopic studies of the erythropoietic and hepatic components of congenital porphyria and erythropoietic porphyria. Clin. Sci. 44, 135150.

40. Vannotti, A. (1954) Porphyrins - Their Biological and Chemical Importance; Hilger and Watts, London.

41. Kaiser, I. H. (1980) Brown amniotic fluid in congenital erythropoietic porphyria. Obstetrics \& Gynecology 56, $383-384$.

42. Tsai, S. F., Bishop, D. F. \& Desnick, R. J. (1988) Human URO-III-S: molecular cloning, nucleotide sequence and expression of full-length cDNA. Proc. Natl. Acad. Sci. USA $85,7049$.

43. Deybach, J. C., de Verneuil, H., Boulechfar, S., Grandchamp, B. \& Nordmann, Y. (1990) Point mutation in the uroporphyrinogen III synthase gene in congenital erythropoietic porphyria. Blood 75, 1763-1765.

44. Warner, C. A., Yoo, H. W., Roberts, A. \& Desnick, R. J. (1992) Congenital erythropoietic porphyria: identification and expression of exon in mutations in the uroporphyrinogen III synthase gene. J. Clin. Invest. 89, 693-700.

45. Boulechfar, S., Da Silva, V., Deybach, J. C., Nordmann, Y., Grandchamp, B. \& de Verneuil, H. (1992) Heterogeneity of mutations in the uroporphyrinogen III synthase gene in congenital erythropoietic porphyria. Human. Genet. 88, $320-324$.

Pr. A. Hassoun

Service de Biochimie Médicale

Cliniques Universitaires St Luc

10 avenue Hippocrate

B-1200 Bruxelles

Belgique 